IRSH 53 (2008), pp. 37-6I DOI: I0.10I7/So02085900700333 I

(C) 2008 Internationaal Instituut voor Sociale Geschiedenis

\title{
From Class to Culture: Immigration, Recession, and Daily Ethnic Boundaries in Belgium, I940s-1990s*
}

\author{
LEEN BEYERS
}

Summary: Each society has myths about the successful adaptation of former migrants. Historians need to deconstruct these myths by dealing with the imagined boundaries between "indigenous" and "foreign" people that give way to them. This essay does so by comparing how children of Polish interwar immigrants and children of Italian postwar immigrants came to be seen as insiders in the Belgian Limburg mining region. Oral testimonies, associational records, and population data reveal that Poles achieved the status of industrious, adapted people around I960, due to the equal promotion of Polish and indigenous miners' sons in the mines and to the labour migration regime which constructed Italians as unskilled outsiders. Around I980, the industrial recession caused unemployment among young Italians. However, migration politics has, since the recession, primarily focused on culture. Moreover, European legislation constructed foreignness as nonEuropean. Consequently, it is not class, but European culture which has turned Italians into "integrated" people.

Let us map out the issue. In Limburg, a Flemish province in the east of Belgium, seven mining towns were built in the first half of the twentieth century. The population of these towns grew from 3,000-4,000 inhabitants in the interwar period, to 8,000-9,000 inhabitants by the I 980 s. The mines and the mine-owned towns, called cités, were developed in the igros in desolate areas that had large supplies of coal. These provisions of coal had been of interest to the industrial world since the beginning of the century. From the ig2os until the global coal recession of the I960s, the local labour market fell short of providing enough miners. Consequently, the mine owners hired many workers from other countries, turning Limburg into the main region for migration in Flanders.

Today, the children of both Polish interwar immigrants and postwar Italian immigrants are seen as "integrated" within the Limburg mining region, while their parents suffered from ethnic inequality and

\footnotetext{
* This article was written with the support of the Research Foundation Flanders - Belgium. I am grateful to Patrick Pasture and the anonymous reviewers for their comments on the first version.
} 
stigmatization. Interestingly however, the context in which they grew up differed significantly. Polish miners' children became adults when the mining industry was in full production, from the I930s to the I950s, while the Italian miners' children reached adulthood four decades later when the Limburg mines were in the final stages of decay. Hence, the question arises of what happened in the two periods to allow the "integration" of the workers' children?

This article starts from the idea that once people of migrant origin come to be "integrated", not only have they themselves changed since the first years of settlement of the migrant group, but also the rest of society has changed, as it starts to perceive the migrant group and its descendants in a different light. In order to acknowledge these mutual changes, immigrant settlement is analysed here in terms of the changing relationships and boundaries between two groups: the established population in the Limburg mining region and the migrant groups. This approach is explained in more detail in the first part of the essay.

Subsequently, the relationship between Polish and Italian migrants' children and their indigenous contemporaries in Limburg is compared. Poles and Italians were the largest groups of non-Belgians in the province in the interwar period and the postwar years respectively. Both migration waves were comprised of workers who quickly brought over their families. Consequently, a high number of children of Polish and Italian

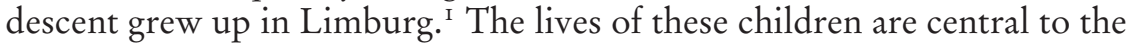
argument, since they experienced the change in inter-ethnic relationships more than their parents.

In this article the local perspective in Limburg is privileged in order to grasp the daily experiences of ordinary neighbours and colleagues with regards to ethnic diversity. The oral testimonies of former inhabitants of the region, records of local associations, population records, and surveys serve that endeavour. ${ }^{2}$ However, the aim of the local focus is not just to tell a particular story about a particular place, but rather to show how daily inter-ethnic relationships in Belgium were shaped and reshaped by changing economic and political dynamics. The concluding thoughts take the history of Limburg as a starting point for some interesting lines of historical inquiry into ethnic boundaries.

I. Frank Caestecker, Alien Policy in Belgium, I840-1940: The Creation of Guest Workers, Refugees and Illegal Aliens (New York [etc.], 2000), pp. I28-I29; Anne Morelli, "L'Appel à la main-d'oeuvre italienne par les charbonnages et sa prise en charge à son arrivée en Belgique dans l'immédiat après-guerre", Revue belge d'histoire contemporaine, I9 (1988), pp. 83-130.

2. Unless otherwise indicated, the oral testimonies used and quoted here were collected for the research Iedereen zwart? on the social history of Zwartberg, one of the Limburg mining towns; see Leen Beyers, "Iedereen zwart? De impact van bedrijf en klasse op de interetnische burenrelaties in Zwartberg, 1930-1980" (Ph.D., Katholieke Universiteit Leuven, 2004) [hereafter, "Iedereen zwart?"]. 


\section{INTEGRATION AND ETHNIC BOUNDARIES}

In recent years, migration historians have increasingly undertaken comparisons of periods and migrant groups. This essay is an example of a "convergent diachronic" comparison, which deals with subsequent migration waves to the same society. On the one hand, convergent diachronic comparisons, like Nancy Foner's seminal From Ellis Island to $J F K$, have revealed surprising similarities between immigrant settlement then and now. For instance, they have shown that former immigrants often experienced as much inequality and stigmatization as newcomers experience today. On the other hand, convergent diachronic comparisons increasingly conclude that the opportunity structures of host societies change considerably over time; hence, the trajectories of migrant groups which are now "integrated" may have been very different, depending on the exact time of settlement. ${ }^{3}$

In fact, at no time did becoming a member of a receiving society imply becoming the same as the "indigenous" people, as the "indigenous" were themselves marked by diversity in terms of religion, ethnicity, class, gender, and so on. In each nation state or, more locally, in each regional context, a particular set of requirements changes people into "indigenous" people in a legal or an imagined sense. Importantly, these requirements change over time, as they depend on the political and social dynamic within host societies as well as on changing international (geo)politics. ${ }^{4}$

These observations require the use of two conceptual strategies for historians. Firstly, they prompt the use of the term "integration" in a descriptive sense, namely in the sense of having or creating a place in any social field, be it a place in parliament, a place as an illegal worker in the hotel sector, or a place within a transnational aid organization. This understanding of integration goes hand in hand with the open question: integration into what? In this sense, integration is largely synonymous with terms like participation, incorporation, and involvement. In contrast,

3. Foner's example has inspired valuable comparisons in western European migration history; see Leo Lucassen, The Immigrant Threat: The Integration of Old and New Migrants in Western Europe since 1850 (Urbana, IL [etc.], 2005); Leo Lucassen, Jochen Oltmer, and David Feldman (eds), Paths of Integration: Migrants in Western Europe (I880-2004) (Amsterdam, 2006).

4. The recent Paths of Integration volume offers striking examples of the impact of changing socio-economic structures and domestic as well as international politics on the requirements for and the trajectories of immigrants. The conclusion of the editors that in the long run integration processes are "at least partly independent of the specific context in which they arise" is therefore surprising. In actual fact, a similar outcome may hide different context-specific dynamics: Lucassen, Oltmer, and Feldman, Paths of Integration, p. 287. On changing national boundaries and requirements for foreigners, see also: Mae N. Gnai, Impossible Subjects: Illegal Aliens and the Making of Modern America (Princeton, NJ, 2004); C.R. Nagel, "Geopolitics by Another Name: Immigration and the Politics of Assimilation”, Political Geography, 21 (2002), pp. 97I-987. 
the normative definitions of integration which are used in western European political and public debates refer to expected ways of participating in society. They impede explorative research, as they go hand in hand with the yes-or-no question: are they integrated or not?s

Secondly, the discovery of the wide variety of routes to integration taken by "integrated" migrants encourages migration historians to study how societies defined who was "indigenous" and who was "foreign". Boundary shifts explain why not all differences between the "integrated" people of migrant origin and the indigenous population disappear. In other words, this provides insight into how even unyielding differences, such as phenotype, religion, or surname, may lose their relevance as an element of distinction. As Richard Alba has recently argued, boundaries between migrant groups and the indigenous majority do not have the same character everywhere, but they always condition the social and economic positions of people of migrant origin. Hence, research on immigrant integration should not overlook the particularity of boundary constructions. $^{6}$

In what follows, the boundaries between the "indigenous" and the "foreign" are called ethnic boundaries, since they have to do with ethnic identity or ethnicity, being people's image and experience of belonging to a group with a common origin and of being distinguished from others with a supposedly different origin. In coining the concept of "ethnic boundaries", Frederik Barth highlighted the fact that the ethnic self-definition of groups, though seemingly stable, changes over time through their relationships with other groups. As a result, in the course of their interaction, the people of Polish and Italian origin, initially categorized as "foreign", came to be perceived as insiders by Belgian-born nationals in Limburg. This did not necessarily imply that the people of Polish or Italian descent lost all sense of their ethnic distinctiveness; rather it implied that being Polish or Italian and being indigenous were no longer fundamentally opposite identities. ${ }^{7}$

5. On the difference between descriptive definitions of integration and the political uses of the term in western Europe: Christian Joppke and Ewa Morawska, "Integrating Immigrants in Liberal Nation-States: Politics and Practices", in idem (eds), Toward Assimilation And Citizenship: Immigrants in Liberal Nation-States (New York, 2003), pp. I-36; Adrian Favell, "Integration Policy and Integration Research in Europe: A Review and Critique", in Alexander Aleinikoff and Doug Klusmeyer (eds), Citizenship Today: Global Perspectives and Practices (Washington, DC, 200I), pp. 349-399; Lucassen, The Immigrant Threat, p. I8.

6. Richard Alba, "Bright vs Blurred Boundaries: Second-Generation Assimilation and Exclusion in France, Germany and the United States", Ethnic and Racial Studies, 28 (2005), pp. 20-49.

7. For this understanding of ethnicity and ethnic boundaries, see: Marcus Banks, Ethnicity: Anthropological Constructions (London [etc.], I996), pp. I I-48 and I I I-I3 I; Stephen Castles and Mark J. Miller, The Age of Migration: International Population Movements in the Modern World (New York, 2003), pp. 32-49; Richard Jenkins, Social Identity (London [etc.], 1996); Frederik Barth, Ethnic Groups and Boundaries: The Social Organization of Cultural Difference (Boston, MA, I969). 
Generally, the indigenous majority has more power in defining whether newcomers are insiders or outsiders than the newcomers themselves. Ethnic-minority formation thus largely results from the power of indigenous protagonists to assign a status to immigrants. In Limburg, the Catholic labour movement and Flemish nationalism were important in this respect. Naturally, people of Polish or Italian origin negotiated their status vis-à-vis the indigenous majority through acts of resistance as well as conformity. Moreover, they constructed ethnic communities for themselves. These identity processes were partly shaped by the dynamics of national identity in their societies of origin as well as in migrant organizations.

However, two structures conditioned the ethnicity of both the indigenous inhabitants and the inhabitants of migrant origin in the mining towns, which is why they receive attention here. On the one hand, the mining industry, which shifted from boom to decline in the r96os, had considerable influence on the inclusion of migrants' children in the indigenous community. On the other hand, the evolving national and transnational migration politics, from the migration of guest workers in the I940s and I950s to the halt of migration resulting from the general recession in 1973 , were crucial to the configuration of ethnic boundaries.

\section{“POLES" AND “BELGIANS" IN THE INTERWAR PERIOD}

Before highlighting the boundary process between the children of Polish miners and their Belgian contemporaries from the I940s onwards, it is necessary to sketch briefly how their parents related to each other in the interwar period. The first specialized miners, engineers, and clerks in the Limburg mines, as well as some of the investors, arrived from Wallonia, the French-speaking part of Belgium, which had a long tradition in mining. The local Flemish men only started to appreciate the higher wages in the mining industry and give up farm work from the second half of the r 930 os onwards. The labour shortage in the I 920 and I 930 s was compensated for through the employment of miners of eastern European and, to a lesser extent, Italian origin. The majority had Polish origins, coming either directly from Poland or from the Ruhr mining region in Germany and the mines of northern France.

With regard to the people of Polish origin, who were considered "foreign" at the time, it is important to keep in mind that until I950, their settlement in the Belgian mining regions went hand in hand with the dreams and actuality of return migration to Poland. ${ }^{8}$ The census of 1930

8. On Polish migration and associations: NIS (National Institute for Statistics, Belgium), Census 1930 and 1947; Caestecker, Alien Policy, pp. 65-255; Idesbald Goddeeris, De Poolse migratie in België 1945-1950. Politieke mobilisatie en sociale differentiatie (Amsterdam, 2005). 
counted 6,055 people of Polish nationality in Limburg, which was roughly one-quarter of the foreigners in the province. In 1947, 8,533 Poles lived in Limburg and 58,542 in the whole of Belgium. A tenth of these are estimated to have been part of the postwar immigration of displaced persons (DPs), who had ended up in Germany during the war and refused to return to their now-communist home countries. Despite DPs' immigration and natural growth, the number of Polish nationals had not increased by much. Actually, many of the Poles counted in 1930 had returned to Poland, either because they could not adapt to the work in the mines or due to the war. A smaller group returned to Poland between 1945 and I950, when Polish communist re-migration campaigns convinced some I0,000 Poles in Belgium to return.

Dreams of return and nationalist exile policies, sparked by the newness of the Polish nation state, marked Polish migration up to 1950. They resulted in an active Polish associational life, with state-related, Catholic, and communist branches, which gradually succeeded in bridging the divide between Poles from Poland and those with German or French backgrounds. Consequently, many Polish miners' children came into contact with Polish language courses and nationalist youth movements before or just after World War II. The start of the Cold War brought migration to and from Poland to an abrupt halt around 1950. At the same time, the local branches of the Polish associations became far less occupied with transnational politics. Those Poles who had not returned to Poland by then threw in their lot for good with the Limburg mines in the absence of other opportunities.

While "Poles" gradually developed a sense of unity in Limburg, the "Belgians" were less cohesive before and during the war. The Flemish miners who worked in the lowest ranks distanced themselves considerably from both the immigrants and the French-speaking Belgian staff. Catholic and pro-Flemish figures of authority inspired these distinctions. From the beginning of the century, Catholic leaders had portrayed the mining industry as alien to the rural province and as spreading socialism and moral degeneration. Hence, eastern European newcomers were, despite being predominantly Catholic, portrayed as immoral and irreligious because they were miners. Ethnic and class boundaries thus interfered from the start of the mining industry in Limburg. Furthermore, the biggest union, which happened to be Christian, as well as Flemish nationalists, claimed that immigration would be superfluous if Flemish miners were treated better by French-speaking staff. 9

9. Tine De Rijck and Griet Van Meulder, De ereburgers. Een sociale geschiedenis van de Limburgse mijnen 1917-1985 (Berchem, 2000), pp. 558-562; Karel Pinxten, Limburg: een colonisatiegebied (Brussels, 1939). 


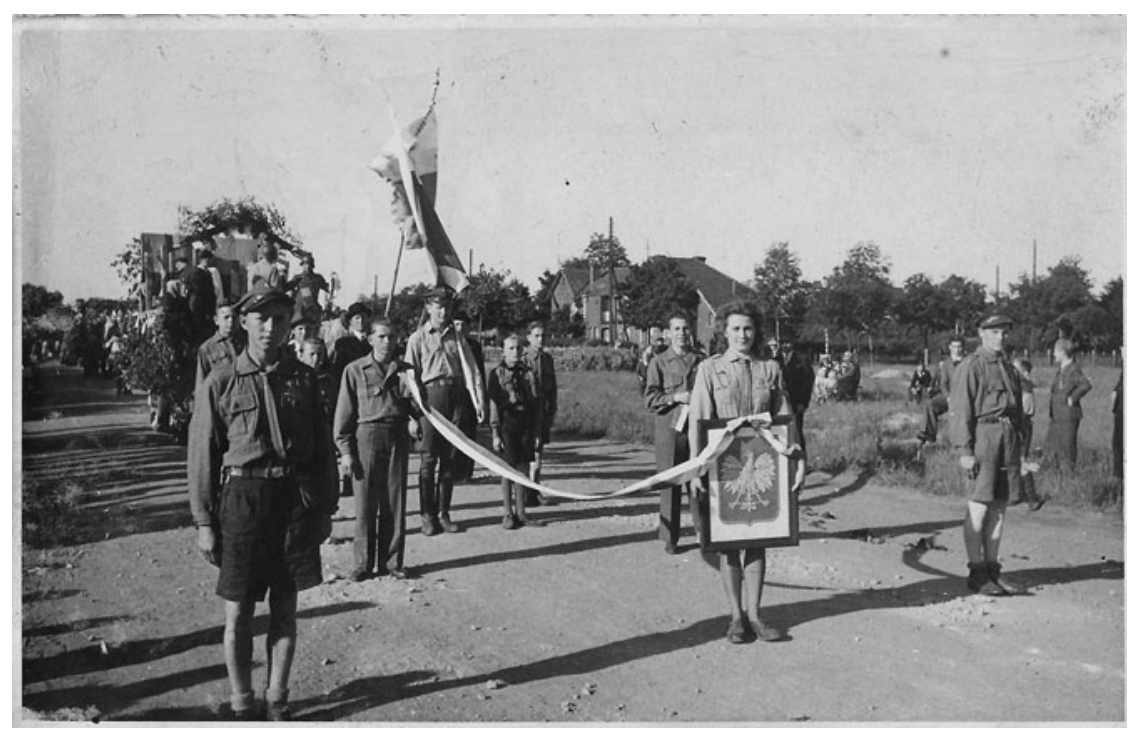

Figure I. Polish scouts participating in a Liberation ceremony in Limburg in August 1945. In the following decades Polish bonding became gradually less pronounced among Polish miners' children who stayed in Limburg.

Heemkring Heidebloemke Genk. Used with permission.

\section{A MINING EDUCATION AND GUEST WORKERS}

Despite the ethnocentrism of their parents, Flemish miners' children growing up in the mining towns began to perceive their Polish contemporaries in a different light. This boundary change can be considered as a side-effect of the paternalistic social policy of the Limburg mining companies, which hoped to attract employees through the provision of housing within the mining towns and the funding of sports and cultural associations. While the first aim of these policies was to tie miners themselves to the company, from the second half of the I930s, the mines created a social programme to attract miners' children to the company. At that time, the mining region was comprised of seven towns laid out like garden cities, which were relatively isolated from the rural habitat of the province. This social space would leave a deep impact on the ethnic identities of the children who grew up in it. ${ }^{10}$

The mines founded mining schools and domestic science classes for boys and girls aged fourteen to seventeen, playing a crucial part in teaching them

Iо. The following overview of the social programme relies on: De Rijck and Van Meulder, Ereburgers, pp. 83-93, 282-31 5, 479-489; Beyers, "Iedereen zwart?", pp. 80-I I I; KBVB (Royal Belgian Football Association), no. 658, membership lists. 
the roles of miners and housewives. The domestic science schools were the result of an attempt to attract miners by providing modern social services for their families. The schools and the lack of female job opportunities in the region effortlessly turned miners' daughters into housewives, dependant only upon a husband who worked in the mine. The mining schools prepared boys for the qualified jobs under ground. Primary school teachers, social assistants working for the company, and engineers convinced their mothers and fathers that mining school was the best choice for their sons.

The mining schools were just one of several different ways used to attract miners' sons to the mine by promising and effectively allowing some economic mobility. Many miners' sons did not choose to go to mining school, but went straight to the mine after their fourteenth birthday, often because of the financial benefits. Both qualified young miners and industrious ones without schooling could be promoted to the specialized positions of foreman and controller. This policy contradicted the view of the Christian union, which until the I950s argued against the promotion of migrant sons. Yet, the promotion was clearly limited to the confines of the mining region. A degree obtained from mining school or experience gained in the mine was not validated by other employers in Limburg, since the mining industry was held in very low esteem in the province at that time. Moreover, migrants' sons were, because of their foreign origin, almost always excluded from jobs outside the mines as well as from those at the mine's surface.

Miners' children from different ethnic origins were brought together not only through education and work, but also in their leisure time. All the Limburg mines invested in a football club, firstly in order to provide young miners with an innocent pastime and secondly to improve the company's prestige. The football clubs soon became the most ethnically diverse associations in the mining region, thanks to the primary school teachers who showed migrants' sons a route into the clubs.

However, first and foremost, the mines were occupied with finding and keeping miners, not with bridging ethnic boundaries. As such, newly arrived immigrants always received housing in one particular segment of the housing stock. This ethnic concentration was aimed at making the mining towns more attractive to xenophobic Belgians. Up until the first half of the I930s, when the number of Belgian miners was limited, segregation was not obvious. The influx of Flemish workers after this increased ethnic segregation, though it still varied from street to street, due to the primacy of occupation over ethnic origin in the allocation of housing and to street-specific migration patterns.

This local, social structure needs to be imposed on the backdrop of the new postwar migration policy in order to understand fully its impact on 
the ethnic boundary processes. ${ }^{\text {II }}$ By the end of the war, the Belgian government had launched the "coal battle", since the recovery of Belgian industry was considered to be fully dependent on the provision of coal. To win the "coal battle", new social benefits were granted to miners. However, it soon became apparent that these measures failed to seduce enough Belgians, and so the Belgian state initiated new recruitment strategies abroad. DPs were invited, but many of them returned to their countries of origin or moved on to the US and Canada after their first experiences in the Belgian mines. As a result, the Italians who arrived after the bilateral agreement between Italy and Belgium in 1946 became the dominant migrant group in the postwar years. The number of people of Italian nationality in Limburg rose from 5, I IO in 1947 to 16, I 26 in I96I and to 22,0I6 in I98 I, by which time they were the largest group of nonBelgians in the province and in Belgium in general. At that time, Belgium counted some 279,700 inhabitants of Italian nationality.

The bilateral agreement anticipated the arrival of 50,000 Italian guest workers, in exchange for the delivery of coal to the ruined Italian economy. ${ }^{12}$ In reality, far more than this number travelled to Belgium, but many returned quickly or tried to find other work. Italians were not eager to become miners for several reasons. Firstly, most of the postwar Italian newcomers came from southern Italy and thus had no experience in mining work. Secondly, in line with the prerogatives of the unions, they were employed in the lowest ranks and had no opportunities for promotion, in contrast to the Flemish recruits. Hence, Italians in these positions tended to work irregularly, behaviour typical of unskilled miners in general. ${ }^{\mathrm{I} 3}$ Thirdly, they were housed in shanty towns, since the mining towns could not immediately absorb this new wave of immigration.

Obviously, these conditions contributed to turning the Italians into the ultimate outsiders. The regional Christian democratic newspaper set the tone, writing in I947 that: "Italians aren't miners and they will never become miners". It also portrayed Italians as "morally low, materially dirty, economically and industrially lazy and socially a big question mark". ${ }^{14}$ Italians were thus constructed as foreigners in economic terms by the powerful Catholic bloc. Until the i930s Catholic protagonists had

I I. On postwar recruitments: Albert Martens, Les immigrés. Flux et reflux d'une main-d'oenvre d'appoint. La politique belge de l'immigration de I945 à 1970 (Leuven, 1976), pp. 63-84; Goddeeris, Poolse migratie, pp. 52-60, I4I-I76, and I85-191; Morelli, "L'Appel”, pp. 83-130; NIS, Census 1947, I96I, and I98 I.

I2. The term gastarbeider (guest worker) became common in Dutch-speaking Flanders in the I960s, after its coinage in Germany at the end of the 1950s. The figure of the migrant as a temporary worker for specific economic sectors was, however, created earlier: Caestecker, Alien Policy, pp. xvii-xviii.

I3. On irregular attendance of unskilled workers, see De Rijck and Van Meulder, Ereburgers, pp. $176-178$ and $183-185$.

I4. Het Belang van Limburg (2 I May 1947), p. I; ibid. (22 June 1947), p. I. 


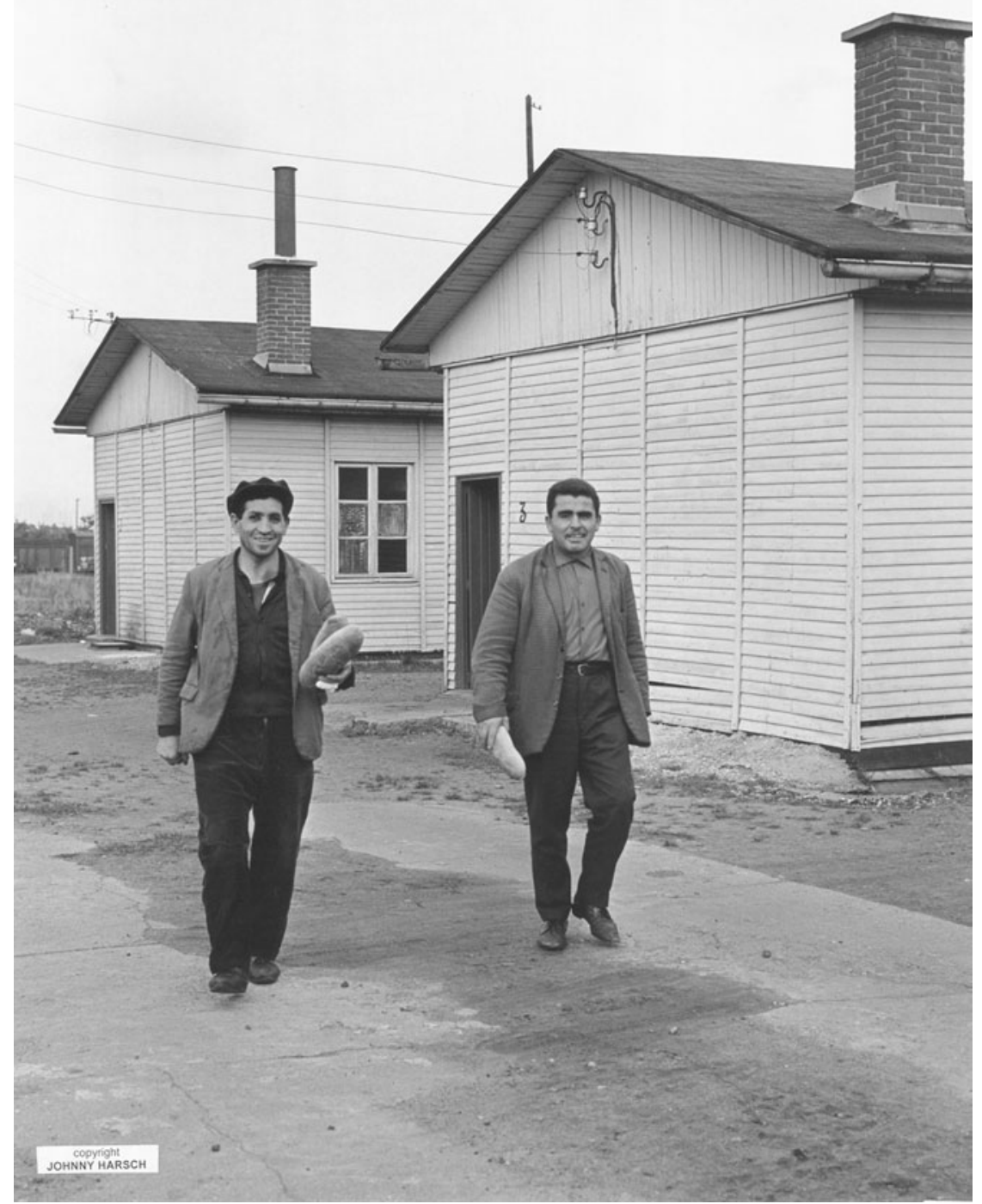

Figure 2. The barracks where Italian newcomers were housed at the end of the I940s had been set up as temporary housing by the Limburg mines, but they remained in use for Italians, Turks, and other newcomers until the beginning of the ig6os.

Photograph by J. Harsch, Werkgroep Mijnmonument Zwartberg. Used with permission.

labelled mining as alien to the province. During the "coal-battle years" the same bloc, now led by the Christian union, appropriated mining work as something indigenous that was to be preserved for the Flemish. The 
Christian union, and the smaller socialist union following in its wake, only tolerated the employment of immigrants in sectors for which no indigenous people were available and repeated that the mines did not want to employ Flemish workers. ${ }^{\text {is }}$

\section{BECOMING MINERS: CLASS AND ETHNIC BOUNDARIES, I $940 \mathrm{~s}-\mathrm{I} 960 \mathrm{~s}$}

In both tense and more friendly contacts between Belgians of the first generation and migrants of eastern European origin, the boundary between "foreign" and "native" remained salient. This boundary would gradually lose its relevance among their children, although this change only started in the I950s and I960s once the Polish and Belgian miners' children had grown up. In contrast, in their childhood and young adult lives ethnic distinctions could still be very dominant depending on the context.

An initial, fragile collective identity came to the fore in the childhood years of miners' children. Children at play were sensitive to spatial boundaries, which in the mining towns largely reflected class hierarchy. As such, ethnic segregation was hazy enough to allow children of different origins to come together. One story they now like to tell is how they played "war" against the neighbouring mining town. Girls were not involved in this game, but they shared a sense of community with others from their quarter, for instance with those they walked to school with. The schools and sports clubs also contributed to this bridging of ethnic boundaries. For instance, members of the local football club experienced that the "we" from the mining town team included boys of different ethnic origins when they played against clubs from other Limburg villages. ${ }^{16}$

These incentives for inter-ethnic bonding were, however, criss-crossed by others, in particular after the end of compulsory schooling at the age of fourteen. From then on, class, gender, and ethnicity drove miners' children apart. In order to sketch where young adults of Polish origin went in comparison to others, I will briefly elaborate on their economic position and experiences with associations and marriage.

Data from a 1962 survey in Limburg give a rough image of the economic positions of young adults of Polish origin. Among I 50 randomly chosen Polish men, of whom 49 were born or educated in Belgium, there was just one office worker and one man with a university degree. In contrast, I 27

I 5. On the attitude of the unions, see Morelli, "L'appel”; Marie-Thérèse Coenen, Les syndicats et les immigrés. Du rejet à l'intégration (Brussels, 2000).

I6. Jan Kohlbacher, "Het jongenspatronaat van Eisden Cité. Een case studie", Ons Heem. Tijdschrift van het Vlaams Verbond voor Heemkunde (1995-1996), pp. 70-87; Fred Vanhinsberg, Waarom die Italianen (Berchem, 1996), pp. 46-47; Beyers, "Iedereen zwart", pp. $210-217$. 
men (or 85 per cent) were underground miners or retired underground miners, whilst I I were skilled workers in other sectors. In other words, few Polish miners' sons left the working class, as was, to a lesser extent, also the case for Belgian miners' sons. Polish miners' sons were promoted within the confines of the working class. Together with Belgian miners' sons and Flemish newcomers, they were hired as specialized underground workers from around 1950, when the Walloon foremen were retiring and the expansion of production as well as mechanization created new demands for skilled personnel. At the same time, their sisters tended to work as domestic workers before marriage and become housewives afterwards. Levels of employment among married women remained very low in the Limburg mining towns until the 1970s. ${ }^{17}$

As for boys of Polish origin, football, mining school, and the mine continued to bring them together with Belgian boys. However, both Polish and Belgian boys formed ethnic peer groups for intimate activities like dancing. The revival of Polish associations and dance halls just after World War II contributed to this ethnic bonding. Moreover, the ethnocentrism of the Limburg countryside made ethnic bonding more obvious among the Belgian and Polish miners' sons of the cités. As a result, migrants' sons faced strong hostility when dating a Flemish girl from a rural village. Incidentally, they experienced a similar ethnocentrism in the mine in the I940s from Flemish newcomers who had not been socialized in the mining towns. In comparison, their contacts with Belgian miners' sons from the cités were at certain times distant, but certainly less hostile. Spatial, company, and ethnic boundaries thus interfered with each other. ${ }^{18}$

Polish daughters, as well as other miners' daughters, were prepared for private roles by parents and schools. Likewise, Polish associations primarily addressed boys. This meant that the network of Polish girls remained quite ethnically diverse, either through their street-bound relations or through their employment as young adults. Nevertheless, compared to their brothers, they married Polish partners slightly more often, partners who they had come to know through the neighbourhood and family relationships, as they were less free to go out regularly and

17. Beda Claes, De sociale integratie van de Italiaanse en Poolse immigranten in BelgischLimburg (Hasselt, 1962), pp. 202-203; Jos Thomas, Genk. Centrum voor nijverheid (Hasselt, 1954), pp. 6I-63; Archives Municipality Genk [hereafter, AMG], Population registers Genk, 1930, 1947, and 196r.

I8. Polish organizations were prohibited during the German occupation, but they rose again after Liberation in the form of very active communist and anti-communist branches. This politicization increased overall membership of Polish associations from an estimated to to $20 \mathrm{per}$ cent; Goddeeris, Poolse migratie, pp. I26-127. On informal ethnic bonding, see Beyers, "Iedereen zwart", pp. 217-227. 
independently. Most of these Polish husbands belonged to the second generation, as Polish immigration halted around 1950. ${ }^{19}$

In sum, Polish miners' children interacted with indigenous contemporaries, but they were equally involved in Polish associations and attached to a Polish network and identity. That people of Polish origin are now primarily perceived as "Belgians", and also tend to label themselves as such, was thus not a straightforward consequence of their upbringing. Instead, it was chiefly related to their position in the mines as adults, which in the particular circumstances of economic boom and massive labour migration had a decisive impact on the ethnic boundary.

Polish and indigenous miners' sons had limited job opportunities, but they did not necessarily see their work in the mines as a limitation. Being a skilled miner became a resource for positive self-identity among them. Equal job positions are of course insufficient to foster a collective identity between indigenous people and people of migrant origin. That it effectively occurred in this case had much to do with the presence of new outsiders in the lowest ranks of the mines.

Their miners' identity became very important to the status of Poles because the Italians were considered to be "foreign" in economic terms by the indigenous community and its Catholic protagonists. The 360 indigenous persons of the Limburg mining region surveyed in 1962 labelled "Italians" as lazy, while they called "Poles" industrious. In this context, Polish miners' sons negotiated their status by emphasizing the differences between themselves and the "lazy" Italians. For instance, a man of Polish origin who formerly worked as controller, measuring the amount of coal produced by hewers, is still eager to mention that there were no Italians doing that job. "They preferred to have Poles and Flemish there", he adds with a sense of pride. One way in which foremen and controllers of Belgian or Polish origin could effectively distance themselves from the newest immigrants was by measuring less coal than was actually produced, which meant less pay, or by assigning newcomers to the worst jobs. It is unclear on what scale this happened, but this inequality of power sharpened the imagined boundary. ${ }^{20}$

19. From I 947 to I95 I 47.7 per cent of the Polish men who married in Belgium (total number: 3,776), married a Polish partner. For Polish women (total number: 3,4 I 7) the percentage was 52.7 per cent; René Clemens, Gabrielle Vosse-Smal, Paul Minon, L'assimilation culturelle des Immigrants en Belgique. Italiens et Polonais dans la région liégeoise (Liège, 1953), p. 32. Marriage patterns were also checked for Polish miners' children in Zwartberg, one of the Limburg mining towns, for the years 1936, I941, 1946, I95 I, and 1956. Only two out of twentytwo young women of the sample were married to Belgians and eight out of twenty-seven young men; AMG, marriage registers and marriage notification registers of 1936, I94I, I946, I95 I, 1956.

20. Claes, Sociale integratie, pp. I64-169 and pp. 173-178. On the power of foremen and controllers, see De Rijck and Van Meulder, Ereburgers, p. I35 and pp. 198-202. The popular narrative that "in the mine everyone was black" idealizes the former solidarity of indigenous 
The ethnic boundaries under ground had a direct impact above ground due to the close relationship between work and housing in the social structure of mining. Miners who were promoted were consequently housed in a better part of the mining town with bigger houses that were preserved for specialized miners and clerks. Furthermore, they benefited from the "coal-battle" measure that granted miners with good records cheap mortgages, enabling them to settle in new private housing close to the mining towns. This promotion to a more desirable quarter was particularly important for the status of migrants' daughters who, as housewives, did not themselves decide where they would live. As a result, both those migrants' daughters who married migrants' sons and those who married indigenous men were invited to join the main women's association, the Katholieke Arbeidende Vrowwen (KAV), if they had settled in a better street after their marriage. This did not happen to migrants' daughters who, after their marriage, remained in the streets "for foreigners", since the Flemish board of the KAV had fewer networks in those streets. $^{2 \mathrm{I}}$

Though economic mobility was crucial for the inclusion of Polish miners' children in the indigenous community, those people of Polish descent who had less successful careers and did not move to a better quarter are also no longer treated as "foreign" in the mining region nowadays. This overall inclusion was only possible by imagining the "Poles" as a homogeneous group of industrious people who all adapted very well to Belgian society.

Indigenous Limburgers had no problem with imagining "Poles" in this way during the 1962 survey. Remarkably, indigenous contemporaries considered "Poles" in a similar way when telling their life stories in 2000. To this end, Flemish contemporaries contested my references to the migrant background of their acquaintances of Polish origin. For instance, when I asked a football club's administrative board if they remembered the first football trainers of Italian and, subsequently, of Polish descent, one of them gave the following reply with regard to "Polish" (and not with regard to "Italian"): "Polish? What do you call a Pole? Those are all Belgians, their parents have been naturalized, their children are [...] I am also married to a Pole, that man was born here. He was born as a Belgian, you should say." The woman speaking was married to a Polish miners' son.

people and newcomers in the Limburg mines. While cooperation in the face of danger undoubtedly occurred among all (miners) who were black, foreign miners of the first generation were nevertheless confronted with inequality and ethnocentrism within the mines. On this narrative, see Leen Beyers, "Unfolding Urban Memories and Ethnic Identities: Narratives of Ethnic Diversity in Limburg, Belgium", in Richard Rodgers and Joanna Herbert (eds), Testimonies of the City: Identity, Community and Change in a Contemporary Urban World. Historical Urban Studies (Aldershot, 2007), pp. I35-136.

2I. Archives L. Severi, Membership list KAV Zwartberg c.1965. 


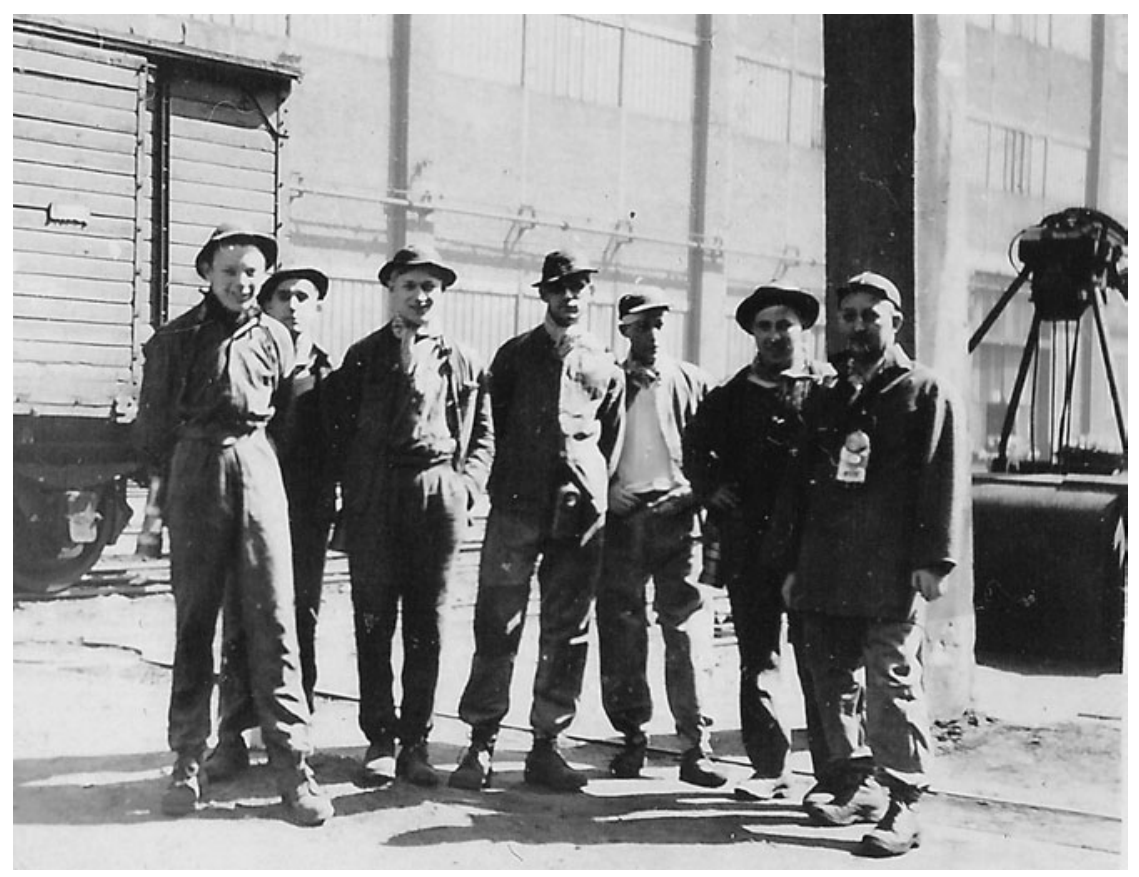

Figure 3. Adjunct-controllers of the coal production of Belgian and Polish origin in 1947. To the right, their (Belgian) supervisors.

Collection B. Maleszka. Used with permission.

Interestingly, she associates naturalization with Poles of the first generation, while in fact it only became commonplace among Polish miners' children. $^{22}$

Polish miners' children themselves actively contribute to this image, by obscuring the "Polish" parts of their lives. My presence as an apparently indigenous interviewer encouraged them in this, which indicates that they still feel the need to negotiate their status. For instance, one Polish miner's son talked about a "Polish" dance venue which he used to go to around 1950. While he celebrated the Polish atmosphere in another part of his life story, when comparing himself with the Italians he emphasized the Belgian character of the place: "Yeah, come on, Polish bars. Poles like us, we all had become Belgians. But the managers there, they were of Polish descent and so on." Similarly, others mention that many individuals of Polish origin married Belgians. After stating this, one man said about his marriage to a 
Polish miners' daughter: "Yeah, by coincidence we are both Polish. My sister is married to a B-, it's a Walloon name, but he's from close to the language border. That's a real Belgian." In fact, given the large number of Polish miners' children marrying Poles in Limburg, his marriage was not such a coincidence.

Hence, people of Polish origin became "indigenous" from the r 960 s onwards, because the ethnic majority had widened its boundaries and come to view "Poles" as insiders. This changed ethnic majority is designated as "the established" in what follows, by way of reference to Norbert Elias's concept pair of "the established and the outsiders". Following Elias, I would argue that the established are not completely similar to each other, but that they share, in part due to their longer presence, the sense of community and the power to turn others into outsiders. ${ }^{23}$

\section{RECESSION AND A MIGRATION STOP}

Despite the social distance between the Italian newcomers and the established people of Belgian or Polish origin, Italian miners' children would come to be perceived as insiders in the i980s. The mining social structure still controlled that boundary process, but it was far less decisive than in the case of the second-generation Poles.

By the end of the I950s, Italian miners and their families had moved from the shanty towns to the old mining towns or to the extensions built in the immediate postwar period. Italian children thus grew up in companylinked towns similar to those of their Polish predecessors. However, things had changed in the meantime. The reopening of the Suez Canal in 1958, which allowed Middle Eastern oil and gas to conquer the European market, had irrevocably involved the Limburg mines in the global coal crisis. The first pit closure occurred in Limburg in 1966 and the last of the seven mines would finally close in I992. Between these years, the social structure of the mines gradually decayed. ${ }^{24}$

Firstly, the recession, as well as the generalization of secondary education and the appearance of branches of Ford, Philips, and other processing industries in the province, undermined the prestige of the mining and domestic science schools. Despite changes to the educational

23. Norbert Elias, "Introduction: a Theoretical Essay on the Established and the Outsiders", in Norbert Elias and John L. Scotson (eds), The Established and the Outsiders: A Sociological Enquiry into Community Problems (London, 1994), pp.I5-52.

24. The following overview of the mining social structure after 1958 relies on De Rijck and Van Meulder, Ereburgers, pp. 255-266; Limburgs Instituut voor de Samenlevingsopbouw, Startrapport met betrekking tot buurtwerken Genk (Hasselt, I978); Beyers, "Iedereen zwart", pp. 23 I328. 
programmes, the mining and domestic science schools, along with the mining profession, increasingly became a second-class phenomenon. As a consequence, it became usual for most boys and girls of the established working class to continue education after the age of compulsory schooling at fourteen and to opt for a well-respected technical or grammar school.

A large group of Italian miners' children was deprived of this opportunity as they trailed behind in school, owing both to their different linguistic and cultural capital and to the educational policies in place. The primary schools in the mining region had reacted to the massive influx of Italian children from 1946 onwards by dividing students by level of performance. Those starting off in the lower levels received an education that did not allow for a promotion to the higher levels later on. Moreover, migrants' children ended up in the mining or domestic science schools after biased advice from teachers or social workers.

Not only the schools, but the mining towns as a whole entered a phase of decline. The public-housing sector and the mines themselves had been encouraging miners to buy or build a proper house by granting cheap mortgages since the "coal battle". Secondly, after the recession of I95 8 the Limburg mines sold off their houses to the occupants and transferred the rest to the public housing sector. Consequently, two groups remained in the mining towns: new immigrants and a few other mining families who could not afford to move, and members of the executive staff who continued to live in the most prestigious houses of the cités. Finally, cutbacks in social investment caused many company-owned leisure provisions to disappear. The football clubs survived, because the commercialization of football had already provided them with other financial means before 1958. These became a key benefit for migrants' sons, even more so than before.

The coal crisis sharpened the boundaries between those who remained in the decaying mining towns and the established who left. In the following years, however, Belgian and European migration policy added another dimension to the ethnic boundary process in Limburg. As part of this, migration between Italy and Belgium has continued until now. The mining disaster of Marcinelle (in Wallonia) in 1956, where 262 miners died, of which I 36 were Italians, provoked Italy into breaking the bilateral agreement of 1946. Nevertheless, after 1956, another 8,000 to 10,000 Italians were still migrating to Belgium individually each year. After a dip during the economic crisis of 1973, this number climbed again to 2,500 people per year in the 1980 . These influxes were balanced by an almost equally intense Italian outflow from Belgium. People of Italian origin in Belgium remained involved in migration thanks to flexible European legislation. Since 1968, members of the European Economic Community 
(EEC) have not required a work permit before migrating to other member states. $^{25}$

At the same time, European legislation promoted the image of foreignness as meaning "non-European". While the Belgian state had restricted labour immigration since the economic recession of $\mathrm{I} 966$ and put a stop to almost all legal labour immigration after the oil crisis in 1973 , members of the EEC were exempt from these measures. In Belgium, the halted "nonEuropean" migration concerned Turks and Moroccans. Despite the coal crisis, they had been employed as miners since 1963 because the established workforce had increasingly left the mines for the new industries. Turks and Moroccans had arrived through collective recruitment, as well as individually on tourist visas. The migration policy in the I960s was so flexible that it winked invitingly at these "tourists". ${ }^{26}$ The restriction of non-European migration later turned Turks and Moroccans into the ultimate outsiders in public and political debates in Belgium.

It is important in this regard that the recession and the migration stop shifted socio-political attention completely to the non-economic aspects of immigration such as the education of the second generation, language learning, and religion. Instead of "guest workers" and "labour market", it was "culture", "multicultural society", and "integration" that were the new keywords of migration politics in the i980s. "Talking culture", as Verena Stolcke has called it, created new boundaries between the "indigenous" and the "foreign". Migrants came to be perceived as fundamentally culturally different, both by those who advocated the right to cultural differences and by those who expected migrants to adapt culturally or to return to their homelands. The Flemish extreme right party Vlaams Blok, has built its electoral success on this discourse from the I980s onwards. However, mainstream politicians also started to talk about a "threshold of tolerance" to cultural differences, thus assuming that "our society" had always been culturally homogeneous. ${ }^{27}$

\section{CULTURE AND HOME OWNERSHIP AS BOUNDARIES,}

$$
\text { I } 970 \text { - I } 990 \text { S }
$$

Like their Polish predecessors, Italian miners' children were only included in the established community after they had reached adulthood. Again, as

25. On these migrations: Nicolas Perrin and Michel Poulain, Italiens de Belgique. Analyses socio-démographiques et analyse des appartenances (Louvain-la-Neuve, 2002); on the EEC policy: Klaus Bade, Migration in European History (Oxford [etc.], 2003), pp. 287-289.

26. Martens, Les immigrés, pp. I I7-i 52.

27. Verena Stolcke, "Talking Culture: New Boundaries, New Rhetorics of Exclusion in Europe”, Current Anthropology, 36 (I995), pp. I-24. On Belgium: Jan Blommaert and Jef Verschueren, Debating Diversity: Analysing the Discourse of Tolerance (London, 1998), pp. 8290 and $9 \mathrm{I}-\mathrm{I} \mathrm{I} 6$. 
children, they were very sensitive to spatial boundaries. The outflow of affluent working-class families increased the ethnic concentration of Italian families in the mining towns and caused ethnicity to be more of a bonding force among Italian miners' children. At the same time, children still distinguished between the miners on the one hand and the remaining engineers or clerks on the other. Hence, they crossed ethnic boundaries most easily within their own class-bound quarter. ${ }^{28}$

When children went to secondary school, these production-related class identities lost their salience in favour of class identities relating to education and, later on, to home ownership. ${ }^{29}$ Furthermore, the trajectories of miners' children started to diverge along the lines of gender and ethnicity. Without going into detail about these trajectories, it is important to indicate the educational and economic positions and the experiences with associations and marriage of Italian children.

Education had become a necessary step to class mobility even more than previously. However, few Italian boys and almost none of their sisters were able to profit from the widened opportunities that education offered in terms of a route out of the working class. Grammar school being uncommon for Italian children, they more often ended up in the higher grades of technical and vocational schools, obtaining qualifications as skilled workers at the ages of sixteen or eighteen. According to the I99I census, only 5.6 per cent of Italian migrants' descendants of the second or third generation in Belgium were in executive professions, compared to I I.6 per cent of Belgians. In contrast, 40 per cent had an occupation in the category of worker or artisan, while the Belgian average was 28 per cent. ${ }^{30}$

A considerable proportion of the Italian children did not realize this mobility from unskilled to skilled positions within the working class. Among the Italian children with the shortest school careers, youth unemployment became a serious problem in the I980s, when not only the pits closed but other industries also suffered from the recession. Though less problematized, the educational and economic positions of Italian girls were, on average, more marginal than those of their brothers. Their parents encouraged them to stay close to home and to protect the

28. Beyers, "Iedereen zwart?", pp. 397-40I.

29. As Mike Savage argues, class positions and identities are not always one-sidedly related to either production-, or market-related economic inequalities, and thus to Marxian versus Weberian understandings of class. In the case of Limburg, however, these two types of class identities were clearly salient in different economic circumstances: Mike Savage, "Class and Labour History", in Lex Heerma van Voss and Marcel van der Linden (eds), Class and Other Identities: Gender, Religion and Ethnicity in the Writing of European Labour History (New York [etc.], 2002), pp. 55-72.

30. T. Eggerickx et al., La population étrangère en Belgique (Brussels, 1999), p. I 25 . The census concerns members of the second and third generations born in Belgium and those of entirely Italian nationality as well as the ones who were of Italian nationality at birth. 
family honour in a passive way. That is why primary school teachers were able to guide them to the local domestic science schools. As adults they alternated between being housewives, working in the local garment industry, domestic work, and unemployment. ${ }^{31}$

Educational integration and participation in associations were clearly linked in the case of the Italian second generation. Some of the Italian boys felt at home in the local associations and venues with a working-class cachet, like the company-related football clubs or the more recreational of the Catholic youth organizations. Others, in particular those with short school careers, resisted these associations once they reached a certain age, as "too Belgian" and formed peer groups with boys of migrant origins from their own quarter. Incidentally, being "Italian" was less relevant to this bonding than being of a migrant background. This can be explained by the disparate initiatives of Italian associations for teenagers which were, in comparison with the Polish case, rarely spurred on by nationalism. Notwithstanding their low level of participation in Belgian associations, Italian boys experienced less ethnocentrism within the mining context than in the rest of the province, for example at dance venues. Though in decay, the mining social space still made a difference. ${ }^{32}$

The participation of Italian miners' daughters in Belgian networks remained even more limited. After the end of compulsory schooling at fourteen, they lost an important stepping-stone into Belgian associations. Interestingly, apart from language classes for primary school children, Italian associations also had little to offer Italian girls. Moreover, Italian parents considered some associations as "too far from home" for their daughters. The Mediterranean family culture tended to keep girls close to home, especially with regard to their courtships, while their brothers travelled the length and breadth of Limburg when going out. Subsequently, Italian girls with short school careers had quite a high chance of marrying an Italian newcomer. They became acquainted with men from Italy either during their holidays in Italy, via their family, or at the small boarding houses that flourished in the Italian neighbourhoods due to the relaxed migration policy for Italians. This is one of the reasons why girls of Italian origin married non-Italians less often than their brothers did. ${ }^{33}$

31. On unemployment and qualifications: Perrin et al., Les Italiens, pp. 50-58.

32. The most steady Italian initiative for the second generation were the language courses at the Italian consulates, but they mainly attracted primary school children: Serge Vanvolsem, "Lingua ed educazione scolastica tra la collettività di origine italiana in Belgio", Studi Emigrazione/ Migration Studies, 42 (2005), pp. 867-893. On associations for Italian youth in Limburg and informal bonding: Beyers, "Iedereen zwart", pp. 280-28I, 34I-342, and 404-4I 3 .

33. In 197757.9 per cent of the Italian women in Belgium who married had an Italian partner. This was the case for only 4I.3 per cent of Italian men; Bastenier, A. en Dassetto, F. "La deuxième génération d'immigrés en Belgique", CRISP Courrier hebdomadaire, 907-908 (I98I), pp. 42-45; Marriage patterns were also checked for Italian miners' children in the Limburg mining town of Zwartberg for the years 1961, 1966, I971, and 1976. Fifteen of the sixty-four 
In other words, the children of Italians and those of other miners did not share one and the same pathway. While local associations still brought miners' children of diverse origin together, the concentration of Italians in certain quarters, the ethnic inequalities in education, and the new Italian arrivals had the reverse effect. It is thus quite remarkable that the children of Italian miners began to be perceived as insiders by the established community within the Limburg mining region once they were adults.

Part of this change in identity may have come from Italian miners' children buying or building houses in the new residential areas surrounding the mining towns, as they came to share a home-owner identity with the other inhabitants, with whom they became familiar through residents' associations and informal reciprocity. The new home owners of established origin and those of Italian origin agreed that they had made the right choice to become home owners and distinguished themselves from the people living in the old mining towns. While they were "on the right track", as one home owner expressed it, they associated the old miners' streets with criminality, decay, and "foreigners", meaning Turks. Italian migrants' children who ended up in respectable home-owner neighbourhoods integrated into associations with an established cachet, such as the women's organization, the KAV, or the board of the main football club. Housing again appeared to be more relevant than inter-marriage to this integration. ${ }^{34}$

Obviously not all Italian miners' children became involved in the networks of home owning. After their marriage, young women of Italian origin often settled close to or in the house of their parents or in-laws in the same low-status neighbourhoods. Other children of Italian descent found a place in new social-housing projects. Nevertheless, "Italians" as a group, including those who lived in less desirable streets and those who had arrived recently, began to be seen as "one of us" from the I980s onwards. A survey from 1990 on the opinions of Belgians about immigrants revealed this change in status. Belgians associated the word "foreigner" far less with Italians than with Turks and Moroccans. Similarly to the Polish case, this inclusion was closely related to the way the new outsiders were distinguished at that time. The European and cultural focus present in post-I 973 Belgian migration politics trickled down into the daily experiences of ethnic diversity in the Limburg mining region. Significant in this respect is that while the mining social structure decayed, the local social programme for immigrants came to reflect national and Flemish politics more closely. 35

Italian women of the sample were married to non-Italians, in contrast to twenty-four of the sicty-six Italian men of the sample: AMG, Marriage registers 1961, I966, 197I, and 1976.

34. Archives L. Severi, Membership lists KAV Zwartberg circa I978-1980; KBVB, no. 658, membership list.

35. On the survey: Jacques Billiet, Ann Carton, and Rik Huys, "The Social Determinants of Xenophobia in Belgium", Recherches Sociologiques, 22 (199I), pp. 65-80. On local social policy: 
When they talk of "culture", inhabitants of the mining towns and the surrounding new quarters often refer to two things: the Catholicism and the European background of "Italians", thus contrasting them with the "Turks". Incidentally, the attacks of 9-I I in the United States reinforced the boundary between Muslims and non-Muslims by adding the association of Islam and violence to the boundary. ${ }^{36}$ In the 1980 s and I990s, however, it was religion framed as "culture" that set Turks apart and stimulated the inclusion of "Italians" into the ethnic majority. In line with the new migration policies, this inclusion was now framed as "integration".

As such, in 1989 volunteers at a parochial Catholic church, who were mainly of established descent, did a survey in order to prepare a new project and concluded that: "Except for the people of Islamic culture Turks and Muslims almost do not integrate, however in Zwartberg their share is small - the integration (of guest workers) with the FlemishBelgian population has gone very smoothly". In fact, the number of Turks was on the rise in that decade due to an extension of social housing in the parish. The distinction of these new outsiders led to the evaluation that all former migration waves had successfully integrated. ${ }^{37}$

The vagueness of the meaning of "integration" in such statements is striking. In the I970s the term "integration" came into use in western European studies and debates on migration as an alternative to the notion of "assimilation", which had become outdated in the wake of civil rights and postcolonial movements. In the liberal sense "integration" meant societal participation rather than cultural adaptation. However, the term soon acquired a pessimistic undertone. "Integration" came to represent a serious problem for people from another culture. The terms "integration" and "integrated" turned into labels indicating that the established considered the culturally Catholic "Italians" as insiders. While they passed off as "integrated" from the I 980 s onwards, Turks were singled out as foreigners..$^{38}$

"Europe" has equally improved the image of people of Italian descent in Limburg. For instance, on the occasion of a community history event in I999, one supporter of the multicultural society created the following rosy image of the former migration waves in Limburg: "I think that in the first

Taak en functie van de Provinciale Dienst voor het Onthaal van Gastarbeiders in een veranderende samenleving. Een visie op migratie en integratie in Limburg na 20 jaar werking (Hasselt, 1984).

36. I observed this difference through doing fieldwork in Limburg before and after 9-I I (from 2000 till 2004).

37. Archives of the parish of Zwartberg, analysis of the parish of Zwartberg, I986-1989, p. 4. See also: Heemkring Heidebloemke, Kolenmijnen en twinwijken te Genk (Genk, I988), p. I4. 38. On the meanings of "integration", see: Blommaert and Verschueren, Debating Diversity, pp. I I I-I I6; Favell, "Integration Policy and Integration Research”, pp. 349-399. 
immigration of Poles, Italians, Greeks, Spaniards and so on, there was still a certain affinity, the Latin-Greek background, the background of our European culture. Moreover, they were all Christians". This construction of the past is fascinating when you consider that Polish miners were discriminated against in the interwar period as irreligious and that the Catholic nature of Italians was not worth a cent until the I970s. ${ }^{39}$

In line with the new sense of multiculturalism, people of Italian descent themselves do not highlight their Belgian character as the people of Polish origin did previously. In order to negotiate their status, they refer to "integration" and "culture" and tend to portray the Turkish newcomers as very different from themselves. For instance, in 1985 the ACLI (Associazioni Cristiane dei Lavoratori Italiani), the main Italian organization in Limburg, presented a report "regarding the positive integration of the Italians into the Limburg community". Yet the report detailed the educational problems and the high levels of unemployment in Italian migrants' children in Limburg. The ACLI also negotiated the status of Italians by using "integration" as the opposite of "assimilation" in order to claim the right to cultural differences..$^{\circ}$

While they seek to associate themselves with Belgians, people of Italian descent have also constructed boundaries between themselves and the Turks in several ways. Some Italians called their Turkish neighbours less clean, a reproach omnipresent in neighbourhood interaction. Others were clearly inspired by post-I 973 migration politics and mention the supposed lack of knowledge of Dutch in Turkish children or the fact that they are not Catholic. For instance, an Italian miners' son says of his youth: "Turkish people were not here then, there was no difference in culture and all [...] Belgians visited the Italian church". Interestingly, the Italian church to which he refers was built in 1962 and at the time elicited a distinct lack of understanding from churchgoing established people, as well as from the Belgian Catholic priest of the parish. A handful of Belgians in search of a personal religious identity did indeed attend the church from 1962, but this in itself did not improve the image of all Italians. ${ }^{4 \mathrm{I}}$

\section{CONCLUDING THOUGHTS: THE HISTORIES OF ETHNIC BOUNDARIES}

By the I960s, the descendants of the interwar Polish immigrants had achieved a status similar to that of Belgian-born people in the Limburg mining region. This was to do with the limited promotion of Polish

39. For more information on the event: Beyers, "Iedereen zwart", p. 56.

40. ACLI Limburg, Italianen in Limburg. Studie nitgevoerd door ACLI Limburg (n.p., n.d. [1985]).

4I. On the Italian church: Archives A. 's Heeren, Inaugurazione Centro Cattolico Italiana, 3 I May I962; Letter of Vicar-General J. Lavigne to parish priest A. 's Heeren, c. I969. 
miners' sons in the mining industry, which brought them onto an equal footing with specialized Flemish miners. These relatively similar roles entailed an enduring collective identity, because the postwar Italian immigrants were specifically discriminated against in terms of occupation. While the Italians were considered unfit for the mines, "Poles" began to be seen as the ideal, industrious immigrants and finally as true Belgians. In order to achieve this status, Polish migrants' children largely gave up their Polish self-definition.

In the I990s, descendants of the Italian postwar immigrants were no longer treated as primarily "foreign" in Limburg. Nonetheless, Italian miners' children didn't take the same routes to integration as those of their Polish predecessors. Firstly, the disparity between their educational and economic achievements and those of established working-class children was greater due to the widened educational opportunities for the latter and the recession. Secondly, the EEC involved Italian miners' children more in a transnational social space. Clearly other things were required this time in order for the Italians to achieve a status similar to that of the ethnic majority. Though locally experienced class identities remained important, the non-economic evaluation of foreigners in post-I 973 migration politics and the construction of foreignness as meaning non-European in the course of the European integration process were largely beneficial in terms of the status of people of Italian origin. They enabled Italian miners' children to become members of the established community while retaining an Italian identity.

Interestingly, similar boundary processes were at work in France and Germany during the twentieth century and their comparison with Belgium should be further developed. As Marie-Claude Bland-Chaléard states, the "world of work" was of utmost importance to the fading of the ethnic boundaries between the French and the descendants of the immigrants settling in France in the inter-war period. The end of the postwar economic boom (the so-called Trente Glorieuses) in the midI970s and the shift to a post-industrial economy caused a weakening of class identification in general. Migration policies "culturalized", and claiming one's cultural heritage, as the Beur movement of young Algerians did in the r 980 s, became a new way of claiming one's place in society. While Muslims found themselves on the other side of the ethnic boundary as a result of this culturalization, in France, and also in Germany, the descendants of the postwar Italian immigrants were included in the established community, despite their limited economic mobility. ${ }^{42}$

42. Marie-Claude Blanc-Chaléard, "Old and New Migrants in France: Italians and Algerians", in: Lucassen et al., Paths of Integration, pp. 46-62. On the importance of working-class cohesion, see also: Philippe Rygiel, "Dissolution d'un groupe ethnique. Origines des témoins et des conjoints des enfants des familles polonaises implantées dans le Cher 1940-1975”, Le mouvement social, I9I (2000), p. 87. On Germany: Yvonne Rieker and Roberto Sala, "Italiani in 
Apart from its comparative value, this local study might have a still wider relevance in terms of inquiry into immigrant settlement. Let me emphasize briefly two points with regard to this. Firstly, historical research continues to be highly relevant in adding the elements of process and generation to migration research. Historians have been emphasizing for a decade how important it is to study more than one generation in order to reveal the long-term processes of change among the migrant population. ${ }^{43}$ I would like to add that it is equally important to pay attention to generational changes among the established population. Ignoring these generational changes amounts to incorrectly constructing the indigenous community of the host society as stable. Things move on all the time, including where so-called "indigenous" people are concerned.

Secondly, historians have a major role to play in deconstructing the myths of the "successful integration" of former migration waves as myths that sustain national communities. Nations promote the perception that migrants adapt to them, and not vice versa, in order to show themselves as homogeneous and stable. Benedict Anderson's insight into the imagined dimension of nations is actually common-sense knowledge in the social sciences in general. However, in studies on immigrant settlement, an awareness of the changing boundaries of the nation is, to date, less explicit. This insight nevertheless sharpens the analysis by showing that paths of integration differ according to the make-up of national boundaries, as well as by revealing that the complete adaptation of former migration waves to "our" homogeneous society is, after all, a myth.

Germania: avvicinamento e disagio", Studi Emigrazione/Migration Studies, 42 (2005), pp. 80682 1; Lucassen, The Immigrant Threat, pp. 162-163.

43. On the relevance (and dearth) of long-term analyses: Jan Lucassen and Leo Lucassen, "Migration, Migration History, History: Old Paradigms and New Perspectives", in idem (eds), Migration, Migration History and History: Old Paradigms and New Perspectives (Berne, 1997), pp. 21-23; Rygiel, "Dissolution”, p. 87. 